\title{
Population Dynamics in Suspension Cultures of an Animal Cell Strain*
}

\author{
Donald J. Merchant, Robert J. Kuchler $\dagger$ and William $\mathrm{H}$. \\ Munyon, $\ddagger$ Department of Bacteriology, The University of Michigan \\ Medical School, Ann Arbor, Michigan
}

Summary. A composite of several studies by the authors is presented in an attempt to illustrate the use of the suspension culture method to analyze population dynamics of an animal cell strain. On the basis of these studies the nature of the lag and plateau phases is discussed. More extensive discussions of the various studies in relation to the work of others appear elsewhere.

\section{Introduction}

Since the demonstration of the suspension or submerged culture method by Owens, Gey and Gey, ${ }^{1}$ and its development by Earle and associates, ${ }^{2-4}$ a number of cell strains, both epithelial and fibroblastic, have been adapted to grow in this fashion. ${ }^{5-11}$ While some of the strains grow as small aggregates of cells, a number grow as monodisperse suspensions when proper chemical and physical conditions are provided. Application of techniques well established in microbiology has permitted characterization of cell growth on a quantitative basis. ${ }^{12-14}$

This presentation will illustrate the way in which analysis of population behaviour has been applied, by us, to the study of suspension cultures of L-strain fibroblasts in an effort to characterize the nature of the cell growth cycle and thus to improve culture procedures. It is of considerable interest that these observations with tissue cells closely parallel the results obtained with bacterial and protozoan populations. ${ }^{15-17}$

* This work was supported by grants C2539 and C3720, National Cancer Institute, by Parke, Davis and Company, Detroit, Michigan and by grant 383 Rackham Funds, The University of Michigan.

† Present address: Singer Memorial Laboratory, Allegeheny General Hospital, Pittsburgh, Pa.

$\ddagger$ Present address: Gorgas Memorial Hospital, Panama Canal Zone. 


\section{Materials and Methods}

The cells used for this study were the L-strain 929 mouse fibroblasts. ${ }^{18}$ Stock cultures were maintained in a protein-free medium composed of chemically defined medium 199 of Morgan, Morton and Parker, ${ }^{19}$ supplemented with 0.5 per cent Bactopeptone as described by Waymouth. ${ }^{20}$ An alternative medium for experimental studies has been Eagle's basal medium ${ }^{21}$ supplemented with yeast extract, lactalbumin hydrolysate and peptone. ${ }^{22}$

For growth of these cells in suspension, it is necessary to add a macromolecular component to the medium to prevent clumping. In some of our studies, 5 per cent whole horse serum was used, but methylcellulose* was found to be more effective. It was added in a final concentration of 0.12 per cent. Growth is quite similar with either compound, though the generation time is somewhat longer in methylcellulose-containing cultures. Their mechanism of action appears to be chemical bonding through polyvalent cations to reactive sites such as free carboxyl groups on the cell surface. The cell surface thus becomes saturated and similar bonding between reactive groups on adjacent cells is prevented. ${ }^{23}$

Under these circumstances the cells were maintained as monodisperse suspensions throughout most of the growth cycle. Only after cell multiplication had ceased did cells begin to adhere to the walls of the culture vessels and to clump. To overcome these difficulties we added a dispersing agent, Darvan $2 \uparrow$, to the medium. This is a compound of a type widely used to disperse clays, dyes and other colloidal materials. It is a polymerized organic salt of a sulphonic acid. In aqueous solution it dissociates to give highly charged anions which coat the cells and impart their negative charge to them. ${ }^{24}$ In a concentration of 0.05 per cent, Darvan 2 is non-toxic and keeps the cells dispersed through the entire growth interval. An additional use of this compound is in solutions used to dilute cells for counting. ${ }^{22}$ Frequently cells which have been adequately dispersed will reaggregate in salt solutions.

The cultures used in the experiments reported here were prepared as follows: cells from a culture in late log or early plateau phase were seeded in growth medium at a concentration of $200-300$

* Methocel 15 cps, Dow Chemical Co., Midland, Michigan.

$\dagger$ Darvan $2{ }^{\circledR}$, R. T. Vanderbilt Co., New York, N.Y. 
thousand cells/ml. Approximately $100 \mathrm{ml}$ of cell suspension was added to each of several 250-ml Erlenmeyer flasks. The $\mathrm{pH}$ was adjusted to approximately $\mathbf{7 . 4}$ and the flasks were tightly stoppered. The cultures were incubated on a rotary action shaker* with a 1 -in. radial stroke at $100 \mathrm{rev} / \mathrm{min}$. The temperature of incubation was $35^{\circ} \mathrm{C}$. The cultures were not gassed.

As shown in Fig. 1, replicate cultures were used to obtain measurements of cell number, packed cell volume, cell size, protein

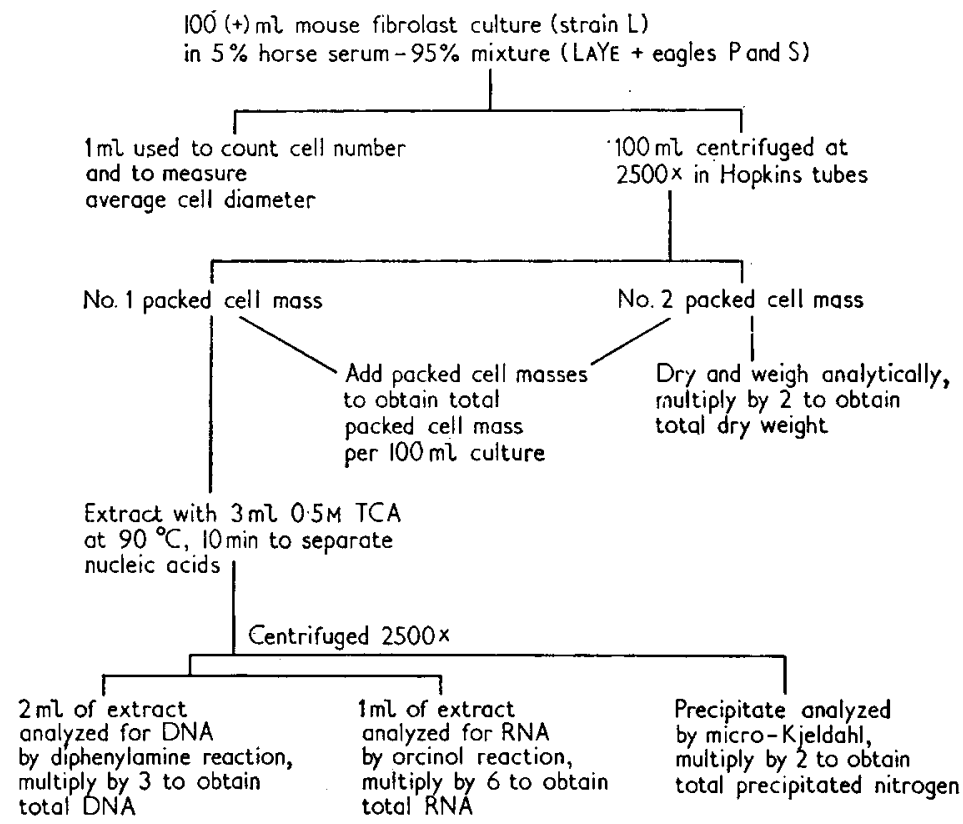

Fig. 1. Analysis of the development of an animal cell population growing in suspension culture

nitrogen, ribonucleic acid, deoxyribonucleic acid and dry weight. Cell number was determined by counts in a haemocytometer or by use of an electronic cell counter. $\dagger$ The latter proved to be of great value as it reduced the counting error from a level of 15-20 per cent with the haemocytometer to approximately 1-2 per cent.

* Eberbach and Son Co., Ann Arbor, Michigan.

$\dagger$ Coulter Electronics, Chicago, Illinois. 
Reduction in time required for counting was also an important factor. Cell size determinations were made either by measurement of diameter with a calibrated ocular micrometer or by direct measurement of volume with the electronic counter. Packed cell volume was measured using Hopkins vaccine tubes. DNA was determined by the diphenylamine reaction, RNA with the orcinol reaction and protein nitrogen by the micro-Kjeldahl method. ${ }^{14}$

In other experiments glucose utilization was followed by making serial determinations of the residual glucose in the medium using the glucose oxidase method. Lactate in the medium was determined by the method of Barker and Summerson. In the latter experiment mean cell volume was calculated from the determinations of cell number and packed cell volume. ${ }^{25}$

\section{Results}

Fig. 2 illustrates the nature of the growth cycle of strain $L$ fibroblasts in suspension. The cultures were inoculated with cells from the early plateau phase of growth. The initial $\mathrm{pH}$ of the

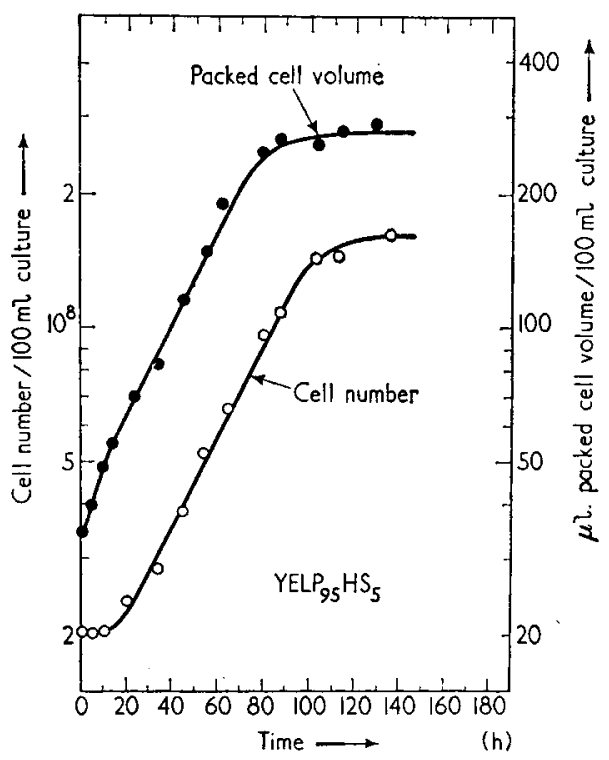

Fig. 2. Relationship of packed cell volume to the number of cells during the growth cycle of $L$-strain fibroblasts 
medium was 7.4. It will be noted that a brief but well defined lag in cell number increase occurred which was followed by 3-4 days of logarithmic population increase. The population normally plateaued at approximately $1 \cdot 5-2 \cdot 0$ million cells $/ \mathrm{ml}$. No medium changes were made during these experiments. The generation time, or the time required for the population to double, can be calculated readily from such a curve and in these experiments ranged from $28-30 \mathrm{~h}$.

A comparison of the curve obtained by plotting packed cell volumes against time in hours with a similar plot of cell numbers indicates several points of interest. It will be noted in Fig. 2 that during approximately the first twenty hours there was a rapid increase in packed cell volume which was not associated with an increase in cell number. Also at the end of this interval the rate of increase in packed cell volume declined. Subsequent experiments indicated that the rate of increase may continue to decline slowly during the entire log phase and packed cell volume increase, therefore, does not exactly parallel the increase in cell number. Finally, it can be seen that increase in packed cell volume can cease as early as 18-20 h before cell number increase stops.

An analysis of cell size distribution during various phases of the growth cycle showed that there were major shifts in size distribution which correlated with the points of difference between cell number and packed cell volume. It will be noted in Fig. 3 that cells at zero time, which had been taken from an early plateau phase culture, were predominately small cells. After $24 \mathrm{~h}$, when the log phase began, distribution of cell size was almost reversed. Within a short time after the culture had entered the log phase size distribution became random. Further studies have shown that the distribution remains random until near the end of the log phase though the mean cell volume may gradually decrease during much of this interval.

When a culture entered the plateau phase, as shown by a cessation of cell number increase, there was an accelerated decline in the mean cell volume which was reflected by an increase in percentage of small cells. At the end of the plateau phase, just before the onset of the phase of decline, the cells were uniformly small but also uniformly viable. Within a few hours, however, viability was completely lost and the cells degenerated rapidly. 


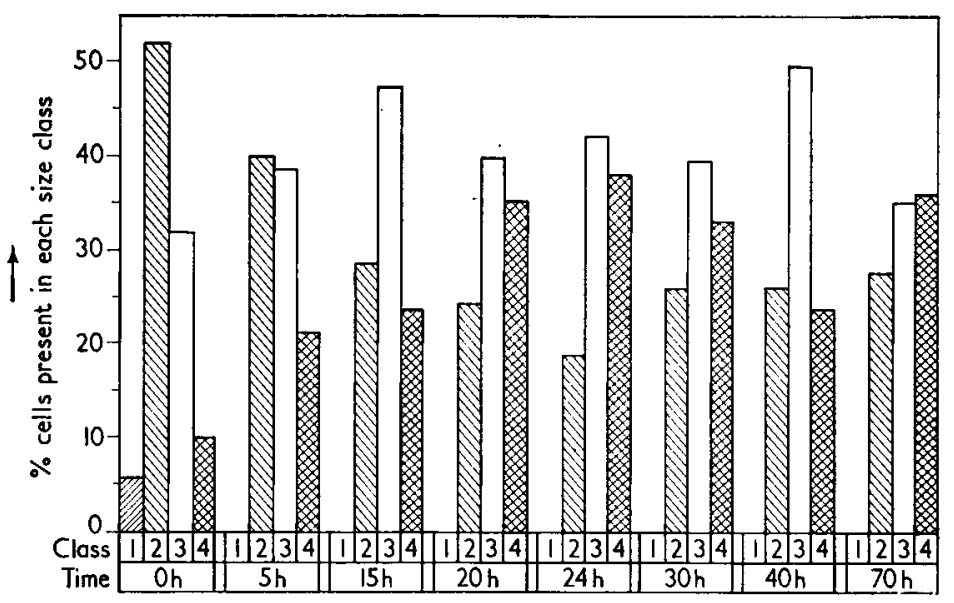

Fig. 3. Cell size distribution analyses at various times during the growth cycle of L-strain fibroblasts

$\begin{array}{rr}\text { Class 1: } 1,150 \mu^{3} \text { cell volume } & \text { Class } 3: 2,150 \mu^{3} \text { cell volume } \\ \text { 2: } 1,500 \mu^{3} \text { cell volume } & 4: 2,950 \mu^{3} \text { cell volume }\end{array}$

Thus it would appear that the lag phase represents a period of growth required to prepare the inoculated cells for division. That such a relationship does exist is further indicated by the fact that when care is taken to properly adjust $\mathrm{pH}$ and temperature the length of the lag phase for the L-strain is directly proportional to the age of the cells used for the inoculum. Thus cells in early logarithmic growth phase showed no lag when put into fresh medium. When inocula were obtained from progressively older cultures from late log to late plateau phases the length of the lag period increased. 26

To clarify further the nature of this relationship, other parameters of population development were studied. Data presented in Fig. 4 suggest at least two mechanisms were involved in the cell size changes noted during the lag phase. In contrast to the changing rate of increase in packed cell volume, dry weight increased in a linear fashion suggesting that the early rapid rise in packed cell volume might be due in part to hydration of the cells. Support for this hypothesis was obtained from studies of glucose utilization. ${ }^{25}$ The data in Fig. 5 show that the rapid 


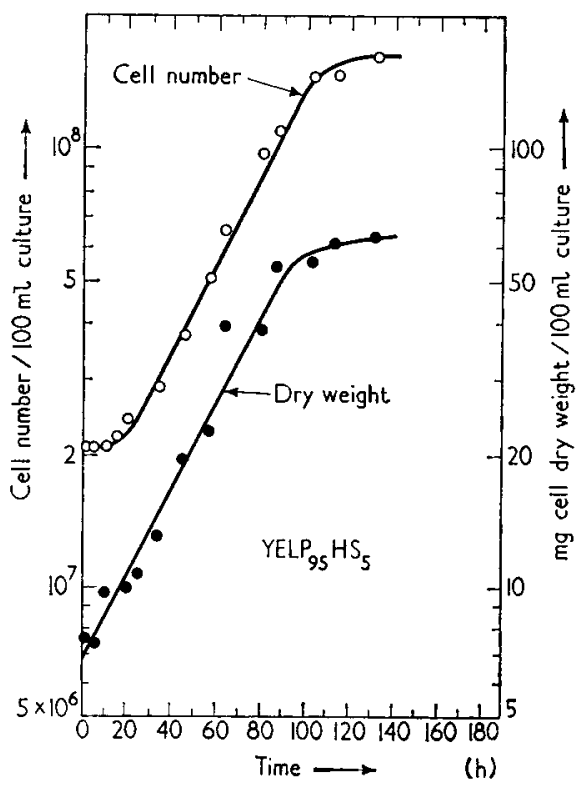

Fig. 4. Relationship of cell dry weight to the number of cells during the growth cycle of L-strain fibroblasts

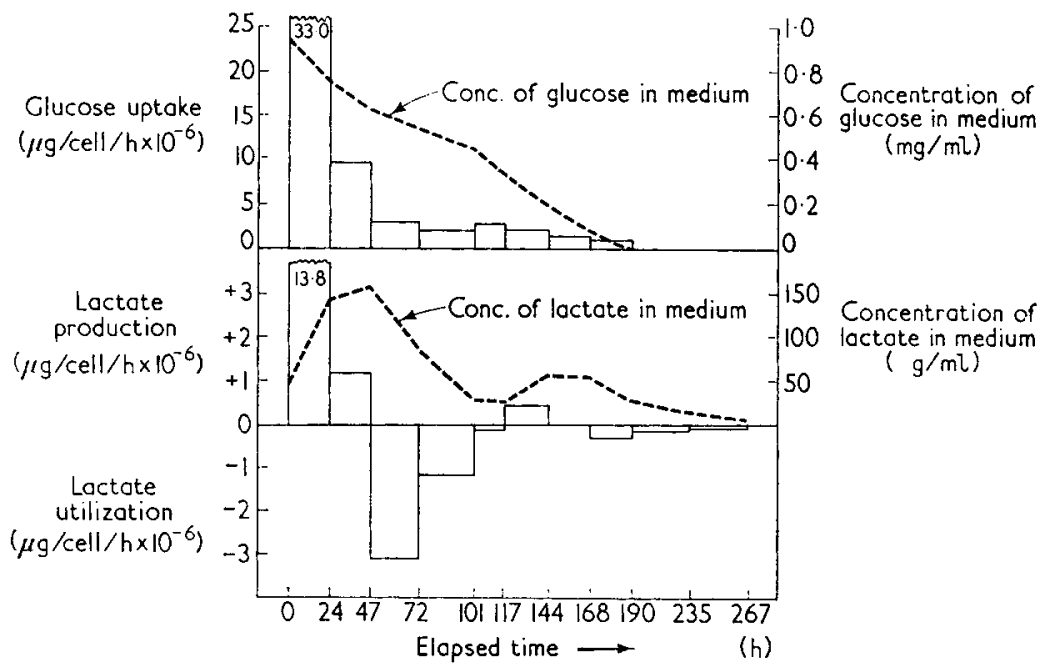

Fig. 5. Utilization of glucose and production of lactate during the growth eycle of $\mathrm{L}$-strain fibroblasts 


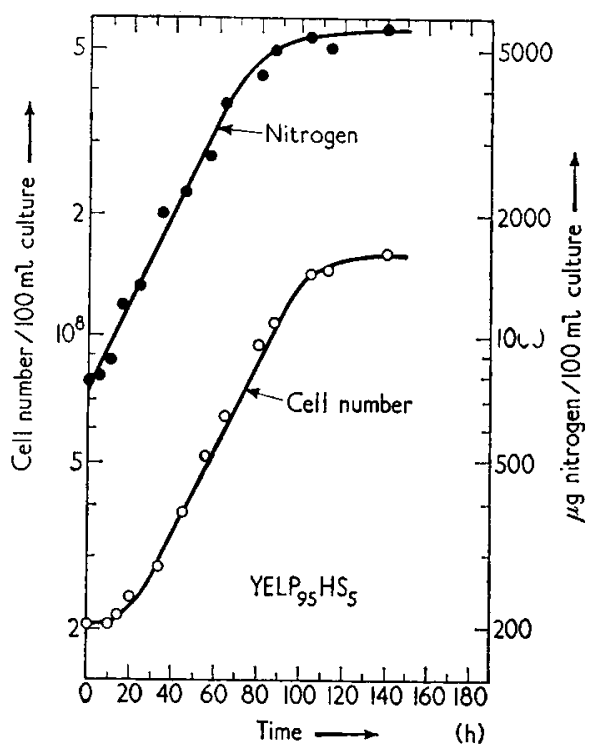

Fig. 6. The relationship of protein content to the number of cells during the growth cycle of L-strain fibroblasts

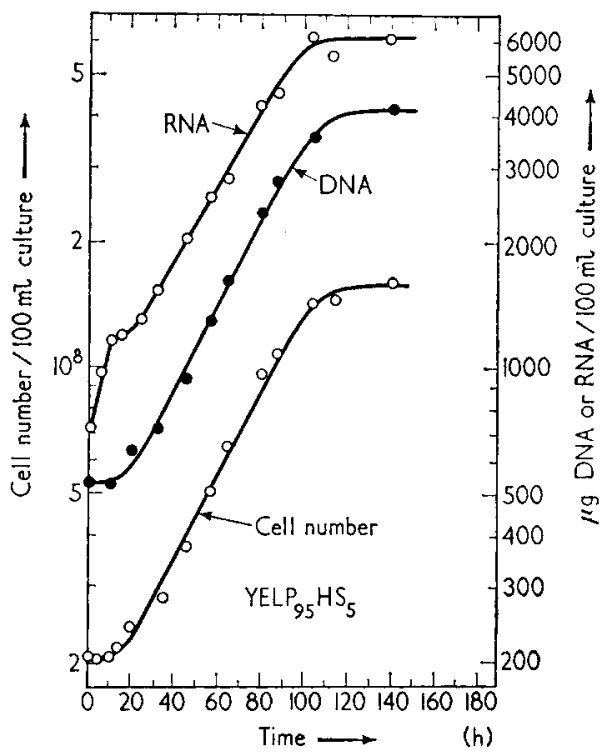

Fig. 7. The relationship of RNA and DNA content to the number of cells during the growth cycle of L-strain fibroblasts 
increase in mean cell volume during the lag phase is correlated with rapid glucose uptake by the cells.

As seen in Fig. 6 protein $\mathrm{N}$ also increased in a linear fashion, thus confirming the results obtained by determination of dry weight. Increase in protein $\mathrm{N}$ stopped before cells entered the plateau phase. From Fig. 7 it can be seen that ribonucleic acid increased most rapidly during lag phase and then continued increasing at a steady, but slower, rate throughout most of the $\log$ phase. Deoxyribonucleic acid followed closely the pattern of cell number increase.

Fig. 8 illustrates some of the apparent relationships between cell number, cell size, cell protein content and carbohydrate utilization

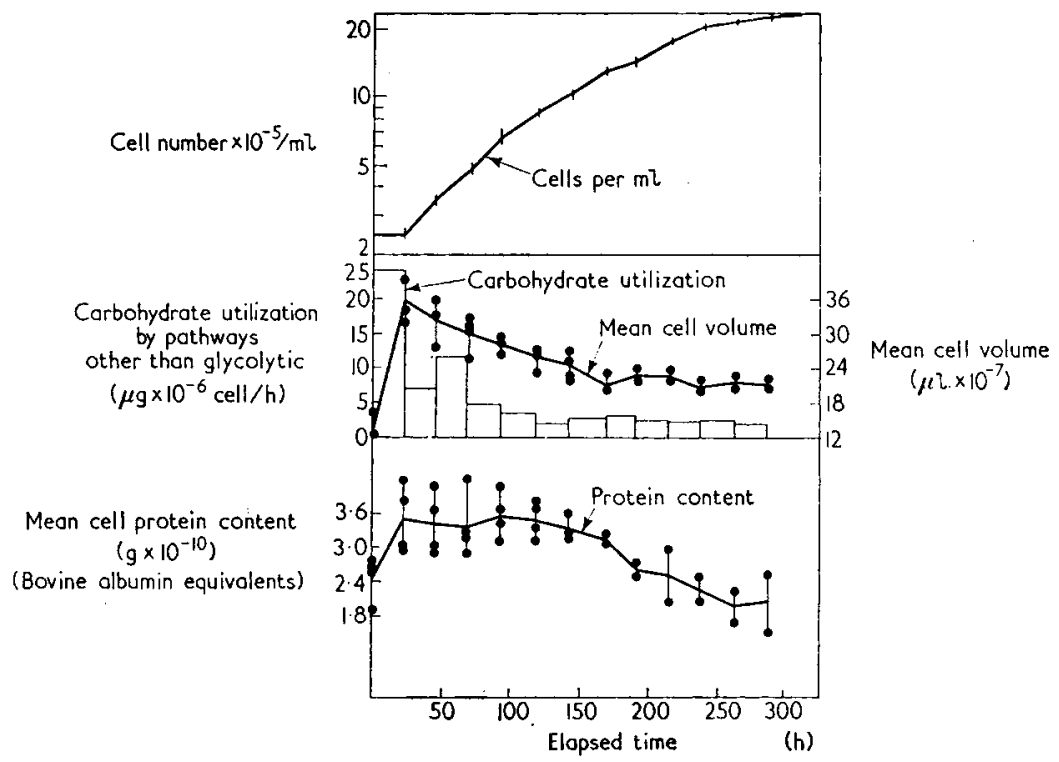

Fig. 8. Changes of mean cell volume, carbohydrate utilization and protein content during the growth cycle of L-strain fibroblasts

by L-strain cells. It can be seen that glucose uptake was most rapid during the lag phase, and, as has been mentioned, a parallel existed between increase in individual cell size and uptake of glucose. Moreover, the protein content per cell increased rapidly 
during this interval. Mean cell volume decreased continuously after the end of the lag period and mean protein content decreased beyond the late log phase.

As seen in Fig. 9 glucose was completely exhausted early in the plateau phase. During the lag phase, when glucose was rapidly taken up, there was a rise in lactate in the medium. Beginning about the midpoint of the log phase this was reversed and lactic acid was removed from the medium until just before platean was reached. At this time a secondary rise in lactate occurred and continued until the glucose was exhausted. Finally the remaining lactate was utilized. The changes in glucose uptake and in lactate production and utilization are quite dramatic when plotted on a per cell per hour basis.

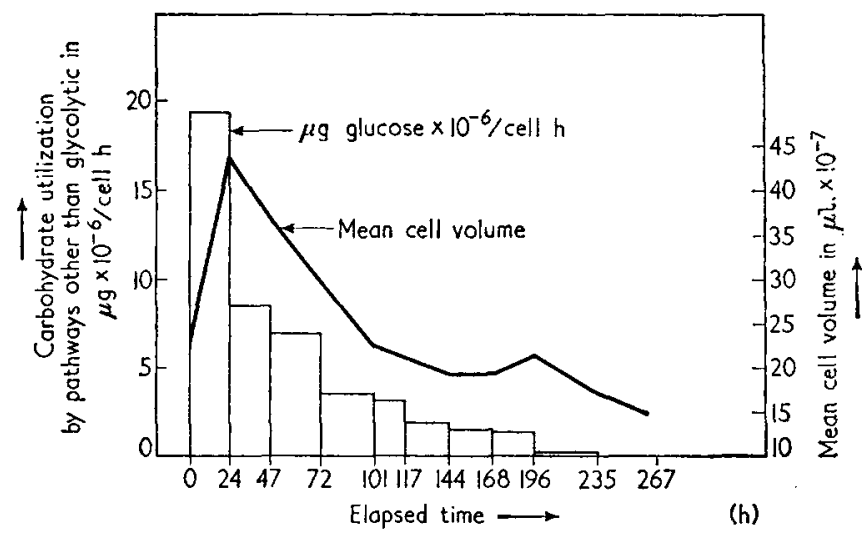

Fig. 9. Relationship of mean cell volume to carbohydrate utilization during the growth cycle of $\mathbf{L}$-strain fibroblasts

\section{Discussion}

We believe the findings reported here to be in agreement with the hypothesis that the lag phase in L-strain cultures normally represents a period of substrate uptake and of synthesis of materials required to initiate cell division. It occurs when the population is not randomly distributed with relation to cell size and hence with respect to the amount of synthesis required for cell division. The smallest cells observed, which ranged in volume 
from 1,200 to $1,500 \mu^{3}$, probably represent cells which have just divided and which must double their size before the next division. The largest cells, ranging from about 2,600 to $3,000 \mu^{3}$, would represent cells which have completed the synthesis needed for cell division. Variation in the ratios of different sized cells in an inoculum would thus be reflected in the length of time required to reach a random distribution characteristic of the log phase.

Further evidence supporting this hypothesis is the observation that cells taken from a culture in the late plateau phase, when used to initiate growth, increase uniformly in size and then divide synchronously. ${ }^{26}$ Since such cells are almost entirely of the smallest size the duration of the lag period, which is about $20 \mathrm{~h}$, should reflect the minimum time required for a cell to carry out synthesis necessary for division.

The reason for the continued decrease in mean cell volume and particularly for the gradual shift to uniformly small cells during plateau appears to be twofold. First, it will be remembered that increases in cell number occurred after there was a cessation of increase in dry weight and of protein nitrogen. This would result as a consequence of the random distribution of cell size if we assume that a portion of the cells had already reached maturity and were capable of dividing without further synthesis. Since these cells could not grow further a skewed distribution of cell sizes would result.

A second factor is related to the observation that glucose is exhausted as the cells enter plateau and that lactate is used up shortly after that. ${ }^{25}$ Assuming glucose to be the major energy source, the cells would be forced to use endogenous metabolism for survival beyond this point. The rapid shift from high viability to no viable cells and subsequently degeneration at the end of the plateau phase suggests that such endogenous metabolism may continue until the structural and functional units of the cell are reduced to a point which is incompatible with cell integrity. Support for this supposition comes from the observation that the plateau phase can be extended from the normal duration of 3-4 days to as much as $2-3$ weeks by a single addition of glucose at the onset of plateau. ${ }^{27}$ No further increase in cell number occurs under these conditions but viability remains high throughout the prolonged plateau. 
A practical application of the information obtained in these studies has been the construction and operation of a continuous cell generator. This apparatus, which is shown in Fig. 10, maintains a constant cell population and a constant chemical environment by changing the medium completely during one generation time. Cells are removed with the used medium. The L strain has been maintained in this apparatus in continuous logarithmic growth for intervals of up to 35 days. The population level was maintained between 400 and 600 thousand cells per $\mathrm{ml}$. The minimum generation time obtained was about $50 \mathrm{~h}$. Medium flow rate was approximately $3-4 \mathrm{ml} / \mathrm{h}$. No attempt was made to gas the cultures.

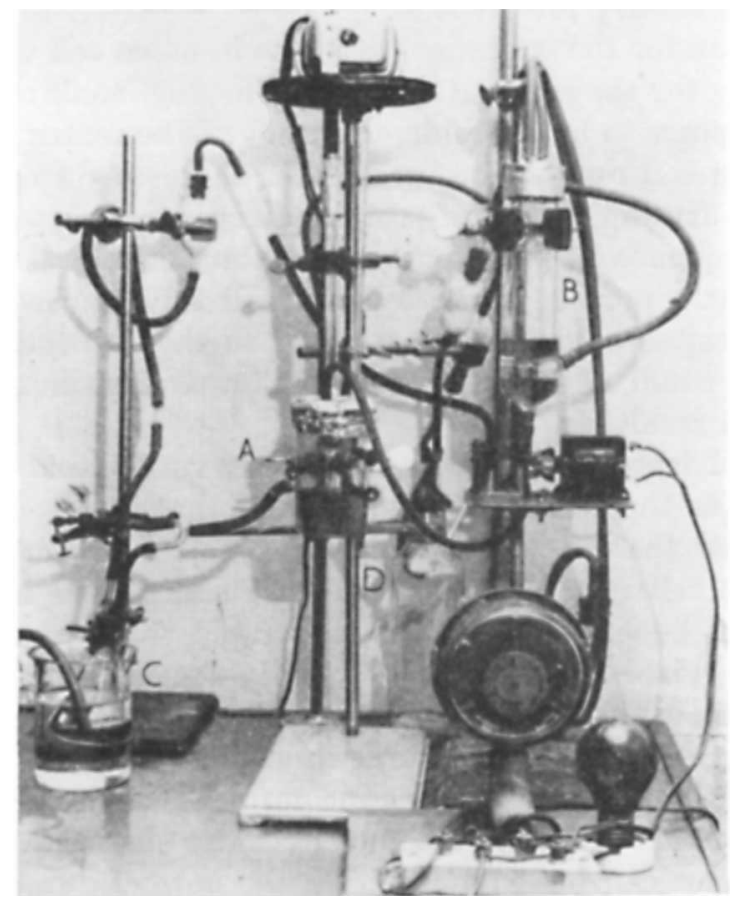

Fig. 10. Continuous cell generator for cultivation of animal cells
A generation vessel
B medium reservoir
C collection flask
D gas reservoir for equilibration 


\section{References}

1 Owens, von H., Gey, M. K. and Gey, G. O. Ann. N.Y. Acad. Sci., 58, 1039 (1954)

2 Earle, W. R., Schilling, E. L. and Bryant, J. C. J. nat. Cancer Inst., 14,853 (1954)

3 Earle, W. R., Schilling, E. L., Bryant, J. C. and Evans, V. J. J. nat. Cancer Inst., 14, 1157 (1954)

4 Earle, W. R., Schilling, E. L. and Bryant, J. C. Ann. N.Y. Acad. Sci., 58, 1000 (1954)

5 Earle, W. R., Bryant, J. C., Schilling, E. L. and Evans, V. J. Ann. N.Y. Acad. Sci., 63, 666 (1956)

6 Bryant, J. C., Schilling, E. L. and Earle, W. R. J. nat. Cancer Inst., 21, 331 (1958)

7 Westfall, B. B., Peppers, E. V., Bryant, J. C., Schilling, E. L. and Earle, W. R. Cancer Res., 18, 947 (1958)

8 Graham, A. F. and Siminovitch, L. Proc. Soc. exp. Biol., N.Y., 89, 326 (1955)

9 Cooper, P. D., Burt, A. M. and Wilson, J. N. Nature, Lond., 182, 1508 (1958)

10 Ziegler, D. W., Davies, E. V., Thomas, W. J. and McLimans, W. F. Appl. Microbiol., 6, 305 (1958)

11 Darnell, J. E., Eagle, H. and Sawyer, T. K. J. exp. Med., 110, 445 (1959)

12 Rinaldini, L. M. Nature, 173, 1134 (1954)

13 Siminovitch, L., Graham, A. F., Lesley, S. M. and Nevill, A. Exp. Cell Res., 12, 299 (1957)

14 Kuchler, R. J. and Merchant, D. J. Univ. Mich. Med. Bull., 24, 200 (1958)

15 Monod, J. Annu. Rev. Microbiol., 3, 371 (1949)

16 Prescott, D. M. Exp. Cell. Res., 12, 126 (1957)

17 Lamanna, C. and Mallette, M. F. Basic Bacteriology. (1953). Baltimore; The Williams \& Wilkins Co.

18 Sanford, K. K., Earle, W. R. and Likely, G. D. J. nat. Cancer Inst., 9, $229(1948)$

19 Morgan, J. F., Morton, H. J. and Parker, R. C. Proc. Soc. exp. Biol., N.Y., 73, 1 (1950)

20 Waymouth, C. J. nat. Cancer Inst., 17, 315 (1956)

21 Eagle, H. Science, 122, 501 (1955)

22 Merchant, D. J., Kahn, R. H. and Murphy, W. H., Jr. Handbook of Cell and Organ Culture. (1960). Burgess Publishing Co.

${ }^{23}$ Kuchler, R. J., Marlow, M. L. and Merchant, D. J. Exp. Cell Res. (In press)

24 Marquis, R. E. and Gerhardt, P. Appl. Microbiol., 7, 105 (1959)

25 Munyon, W. H. and Merchant, D. J. Exp. Cell Res., 17, 490 (1959)

26 Kuchler, R. J. and Merchant, D. J. Unpublished data

27 Merchant, D. J. and Koth, S. R. Unpublished data 